\title{
Ascending Testicle
}

National Cancer Institute

\section{Source}

National Cancer Institute. Ascending Testicle. NCI Thesaurus. Code C123257.

A condition in which a previously descended testicle permanently moves out of the scrotum. 